\title{
TWO IMPORTANT WEST INDIAN SEED-INFESTING CHALCID WASPS
}

By Herbert L. DOZIER

Formerly Chief Entomologist, Insular Experiment Station, Río Piedras, P. R.

The following brief and incomplete notes are presented here in order to call attention to two seed-infesting chalcid wasps in the hope that they will be studied further by other workers as the opportunity occurs. Both are of much economic importance but the damage occasioned by them has heretofore been completely overlooked. Although our knowledge of the distribution of these species is extremely limited, they undoubtedly will prove to be present on most of the islands of the West Indies and, possibly, wherever their host plants occur.

The writer wishes to express his thanks to Mr. A. B. Gahan of the U.S. National Museum for his kind assistance in placing these species generically.

\section{THE LOGWOOD OR CAMPECHE SEED CHALCID}

In 1890 , Dr. L. O. Howard erected the genus Tanaostigma to include a single species, T. coursetiae Howard, from the ovaries of a rare leguminous tree, Coursetia? mexicana Watson, in Mexico. In commenting on this unusual and supposedly phytophagous encyrtid he states that "We must leave it for future field observations upon this or upon some congeneric species to definitely settle this most interesting point". It is therefore exceedingly interesting to present, after a lapse of 42 years, a second species of the genus with conclusive proof of its phytophagous habits.

Dr. Giuseppe Russo has rather recently (Bol. Lab. Zool. Portici, vol. xxIv, pp. 132-139, 1930) deseribed the new genus Cubaniella based on the single species Cubaniella trotteri Russo, from galls of Belaira mucronata Gris, collected at Santiago de las Vegas, Cuba, by Dr. S. C. Gruner. He places his genus in the subfamily Perilampinae Howard. His material represents a genus undoubtedly very close to Tanaostigma Howard, placed by Dr. Ashmead in a distinct tribe Tanaostigmini of the subfamily Eupelminae. Members of this tribe show certain relationships with both the Perilampinae and the Eurytominae as well as with the Eupelminae and it is a mooted question as to where they properly belong. The description of the Cuban 
species, unfortunately, is based only on the female but is sufficient to show its close relationship with the new species from the seeds of logwood.
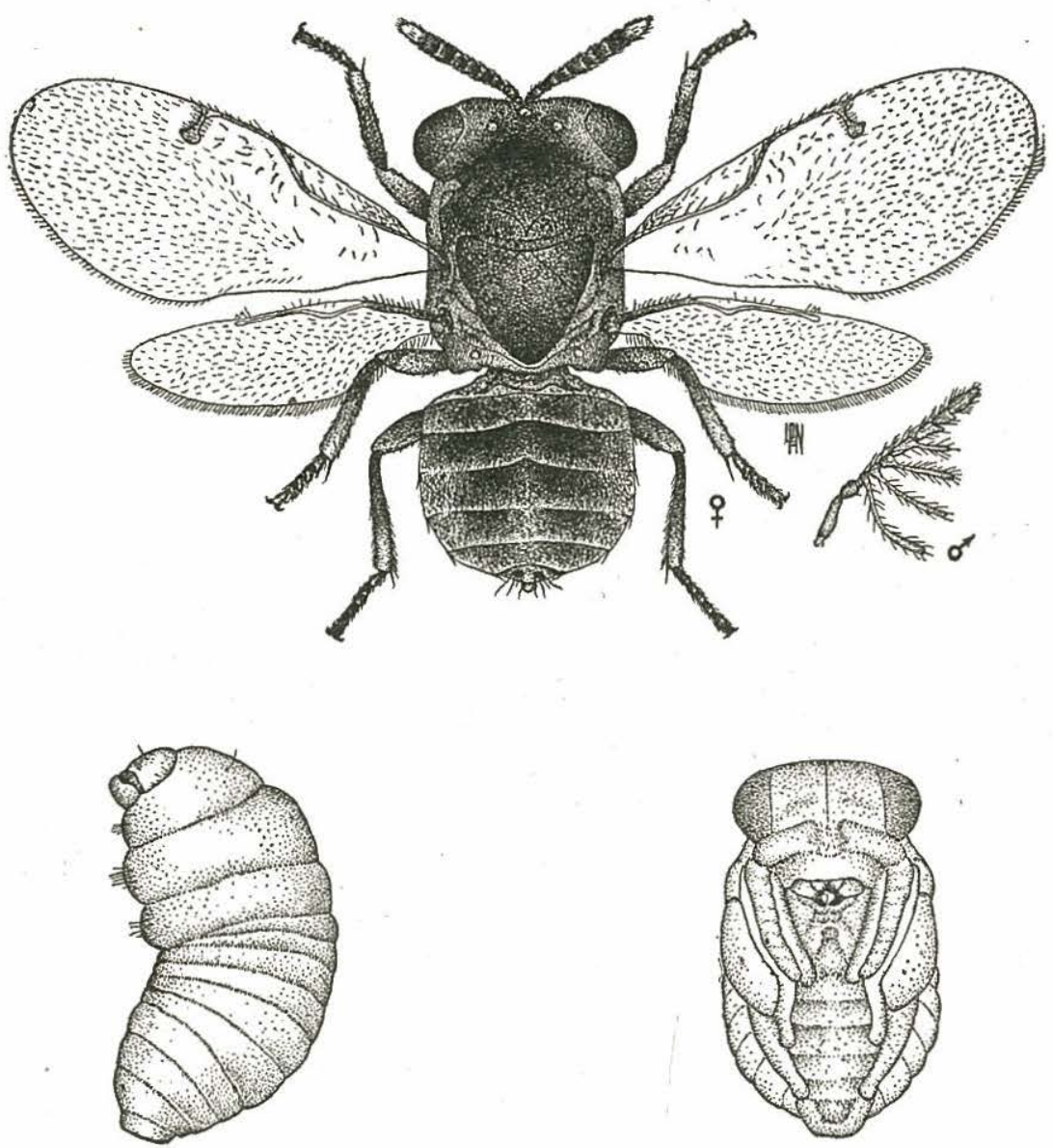

Fig. 1.-Adult female of the logwood seed chalcid, Tanaestigma haematoxyli Dozier, male antenna, full-grown larva and pupa, all greatly eniarge (original)

\section{TECHNICAL DESCRIPTION}

Tanaostigma haematoxyli, new species.

This species appears to be much stouter than T. coursetiae Howard and differs from that species distinctly by its different coloration and 
by having the female scape less flattened. Both sexes of this species show considerable variation in size but the male is usually decideclly smaller. The variation in size of individuals is due most probably to different moisture conditions and food available in different seed pods.

Female. Length 1.21-1.46 mm.; expansion $2.84 \mathrm{~mm}$; greatest width of forewing $0.573 \mathrm{~mm}$. The general appearance of the female is stout and compact, the thorax decidedly lumped or convexly elevated; slightly pubeseent with light colored hairs. General color a dark honey-yellow, the vertex and more dorsal portions of the thorax and abdomen more or less infuscated giving a fuscous appearance except along the sides; the sides of the abdomen are pale in color. Antennae dark brown except the pale ring-joint and the white elub; 11-jointed; club apparently solid; pedicel nearly twice as long as wide, followed by a small ring-joint and a second larger and darker joint that borders on being a true ring-joint, decidedly smaller and narrower than the funicle joints which are subequal in length and only slightly widening to the elub. Head transverse. Pronotum narrower than the head and slightly longer, the scutellum convexly elevated, with reticulate markings or areas on surface. Forewings hyaline, venation pale brown, the stigmal vein very thick, covered with numerous eurved setae. Under high magnification, specimens mounted in balsam, show the thorax and abdomen to be distinetly retieulated. Legs brown, the hind tibiae armed with pale rigid bristles along the inner margin.

Male. Length $0.86-1.37 \mathrm{~mm}$; expansion $2.65 \mathrm{~mm}$; greatest width of forewing $0.502 \mathrm{~nm}$. Easily distinguished from the female by its smaller size, narrower and more slender build, lighter coloration, and immediately by its branched antennae. Gencral color similar somewhat to that of the female but lighter yelIowish. Antennae 13-jointed, composed of a ratler broad seape, short stout pedicel, a pair of minute ring-joints, theh next five funicle joints increasing in length, ench one with a lateral prolongation, sucessively shorter, giving a branched appearance; the last funicle joint is slightly shorter than the two preceding and has only a suggestion of a short lateral prolongation.

Described from a large series of both sexes, mounted on cardpoints, in balsam on slides, and in alcohol, U.S. National Museum Type No. 43939; reared in vast numbers from seeds of logwood, Haematoxylon campechianum L. Hinche, Haiti, Jan. 18, 1930, and at Damien, Haiti, Feb-March 1931 by the writer.

Larva. Length $.85 \mathrm{~mm}$. The fullgrown larva is 13-segmented, the anterior three segments being distinctly wider than the remainder. Pale creamish white in color.

Pupa. Length $1.75 \mathrm{~mm}$; greatest width $.75 \mathrm{~mm}$. Pale creamish color at first but as development proceeds the eyes become distinctly reddish and the mandibles take on a reddish, chitinized appearance. Just prior to issuance of the adult, the pupa becomes very much darkened. 


\section{DISTRIBUTION}

The logwood is indigeous chiefly to the mainland of tropical America, being most abundant in southern Mexico (Tobasco, Campeche and Yucatan) and throughout Central America, and fairly common in Ccombia, Venezuela and the Guianas. It seems to be possibly native to Hispaniola, as the wood is said to have been exported from Santo Domingo to Spain in the latter part of the sixteenth cen-

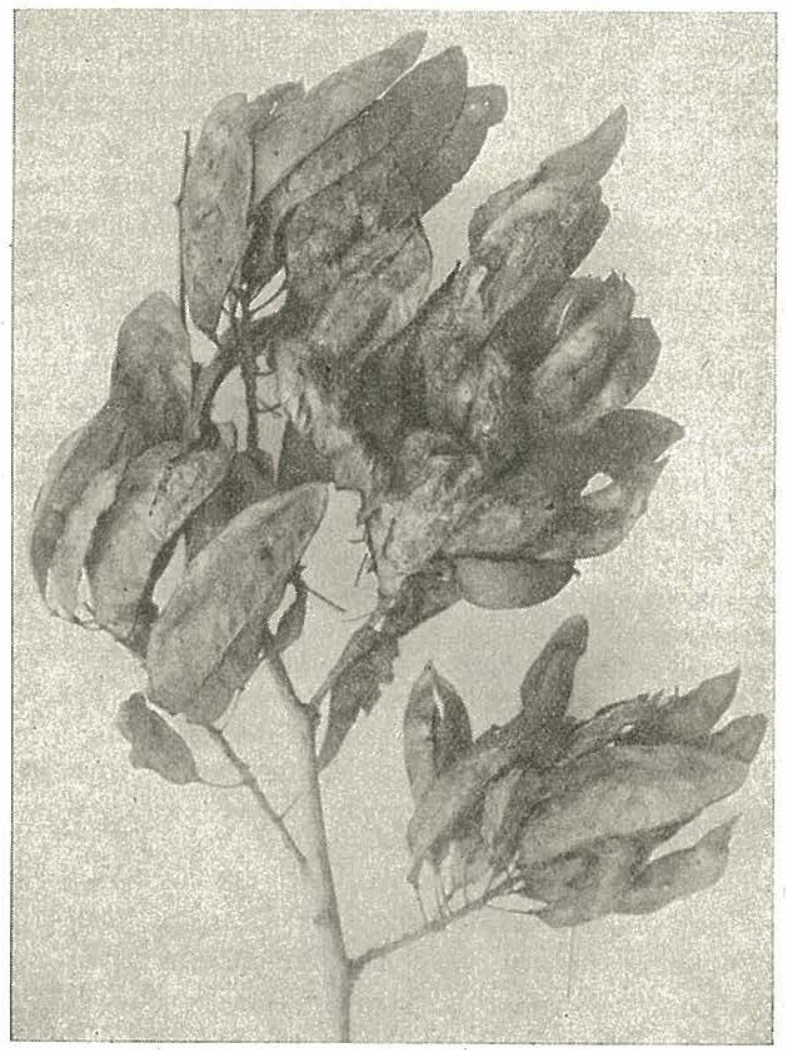

Figure 2.-Cluster of logwood seeds, completely destroyed by the work of

Tanaostigma haematoxyli, new species, slightly reduced (original)

tury. It is called "campeche" in Haiti, and there as well as in Jamaica is the chief honey plant of the island. It was reported as having been introduced into Jamaica about 1715 by means of seed from Honduras. It would therefore be very interesting to find out if the seeds are attacked by this wasp in the other parts of its range.

A letter from $\mathrm{Mr}$. H. H. Coote, Instructor in Beekeeping in Ja- 
maica, dated Feb. 25, 1930, states "From the beekeeping standpoint we look at the logwood as a great asset and although it is attacked here by a similar insect we have no reason to be alarmed as we have more young trees coming forward than those that are cut down for commercial purposes". In Haiti, however, the logwood is being rapidly and relentlessly cut out for export for the dye industry and this together with the destruction of 90 per cent of its annual seed crop by this wasp accounts for the diminishing amount available in that country and for the poorer honey yields of more recent years.

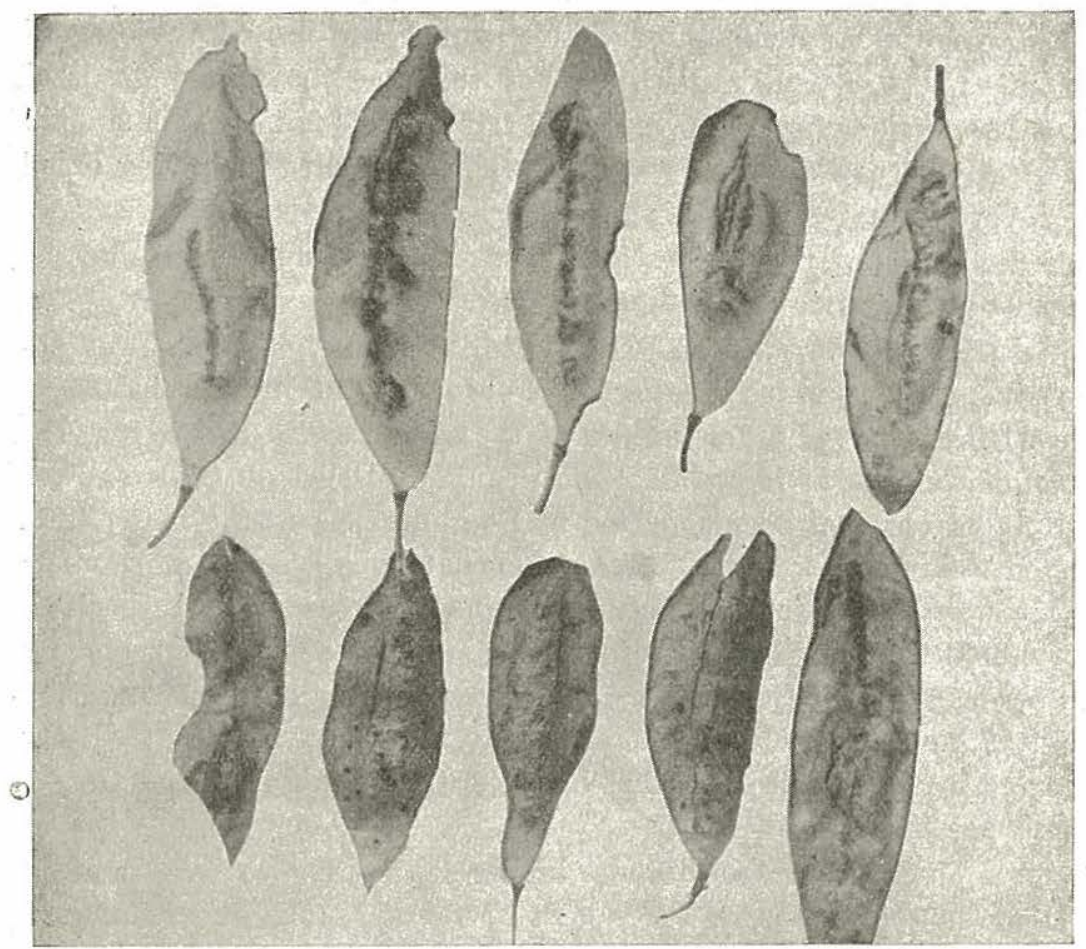

Figure 3.-Seed-pods of logwood, Haematoxylon campechianum L., in various stages of development, showing oviposition sears and exit holes, natural size (original)

\section{SEASONAL OBSERVATIONS}

The main flowering of the logwood and consequent honey-flow in the vicinity of Damien, Haiti, starts in January and there is nearly always a second blooming. In other sections of the island there are as many as three different extractions. In the Hinche region the log- 
wood usually starts to bloom about November 29th with the largest honey-flow starting again in January. As the logwood is rather irregular in blooming we find usually some straggling or late blooms at the same time as young and fully-developed pods and as the blooming season varies with different regions it appears that this wasp carries itself over from one season to the next without difficulty.

The writer observed the logwood in full bloom at Hinche, in the Central Plains district, on Jan. 9, 1930. On this date vast numbers of a very small greenish-yellow psyllid, nymphs and adults, were present on every flower cluster examined and these were turning black and drying up as a result of the continual sucking of these small insects. Old seed pods still elinging to the trees showed hundreds of adult Tanaostigma issuing. A second trip made January 16th showed practically no new seed had set, all of the flower clusters having dried up. Automatically with this the honey-flow ceased. From the old pods thousands of the Tanaostigma were still issuing to continue the destruction of any seed that might have set.

At Damien and Port-au-Prince adult Tanaostigma, the first observed in 1930, started issuing on February 2nd in vast numbers. The writer observed a few adults of the same psyllid and a few Tanaostigma adults at logwood bloom near St. Michel du Sud on Feb. 17th and from seed pods collected at Fond-des-Negres the first adults started to issue Feb. 18th. During February observations were made by Messrs. G. Kolbjornsen and A. Daumec, Agricultural Inspectors, throughout the entire Artibonite valley and they reported practically 100-per-cent destruction of logwood seed wherever examined, finding only exit holes as the adults had already issued. Attacked seed was reported by Mr. Parisot at Thozin in the Commune of Grand Goave, March 16, 1930.

Close observations were made during 1931 . The logwood started to bloom in the regions of Port-au-Prince and Damien about January 1st. At Verrette the writer observed newly formed pods with very young larvae of Tanaostigma developing inside the seeds on Jan. 15th. By February 28th the large new crop of seed pods at Damien shawed 100-per-cent infestation but only a few of the adults had issued by that date. A large amount of material was placed in battery jars and field observations continued. By March 20th nearly all of the adults had issued. Due to the prolonged flowering, even at that date there were a few late blooms on the same trees and the young pods practically all contained pupae. 
The adult wasps soon after issuing were observed to start mating; actively running over the seed pods. The eggs are extremely small: and are deposited within the young tender pods by means of the ovi positor. The oviposition scars are readily visible from the outside and each seed is occupied by a larva. The consequent reaction produces a gall-like deformation of the seeds and with it the pod is definitely thickened along the middle. Fig. 3 shows various seed pods; illustrating the different stages of development from the oviposition scars to the exit holes of the adults.

The result is that in many cases every seed in the entire cluster of pods is completely destroyed. In this way the logwood is prevented from re-seeding itself. Observations made over the two-year period show that this is serious. Fortunately, however, the logwood is so prolific that it is probably capable of producing enough seedlings to replace itself if freed, even at long intervals, from the attack of this wasp by unusual activity and restraint on the part of its parasites.

\section{PARASITISM}

On March 16, 1931, the contents of one rearing jar were examined and counted with hand tabulators, yielding 5223 adult Tanaostigma and 352 parasites or 6.75 -per-cent parasitism. There were two species of parasites involved and these have been determined by $\mathrm{Mr}$. Gahan as Eupelmus sp. and Horismenus sp., the latter being the smallest and of a distinet metallic green color.

\section{The Annona Seen Ghalcid}

\section{DISTRIBUTION}

This rather large chalcid wasp, Bephrata cubensis Ashmead, was described in 1894 (Descr. New Parasitic Hymneoptera, Trans. Am. Ent. Soc., vol. 21, p. 321, Sept.). The first record of its attacking Annona seeds was that published by J. C. Crawford (Proc. U. S. National Museum, vol. 41, p. 274, 1911). There are specimens in the U. S. National Museum, determined by $\mathrm{Mr}$. Gahan, reared from Annona seeds at Santiago de las Vegas, Cuba, by P. Cardin, Dec. 26, 1910; from seeds of the custard apple and sour sop at Cross Roads, Jamaica, A. H. Ritchie; and from Annona squamosa fruit at Miami, Florida, Dec. 15, 1921, reared by G. F. Moznette. In addition, the writer observed the exit holes of this insect to be numerous in fruits 
of the "guanábana", Annona muricata, in Porto Rico in 1925 * and has reared adults in Haiti in 1931. This shows that Bephrata cubensis has a rather wide range through the West Indies at least and occurs in Florida.

\section{TECHNICAL DESCRIPTION}

Female. Length $6.5-7.25 \mathrm{~mm}$. Of a testaceous to rufous-orange color when fresh, except for the petiole and last thoracic joint adjoining which are black. Antennae with seape pale, marked with fuscous adjoining the dark pedicel; the entire funicle deep brownish-orange, turning darker after death. Eyes red. Ocelli

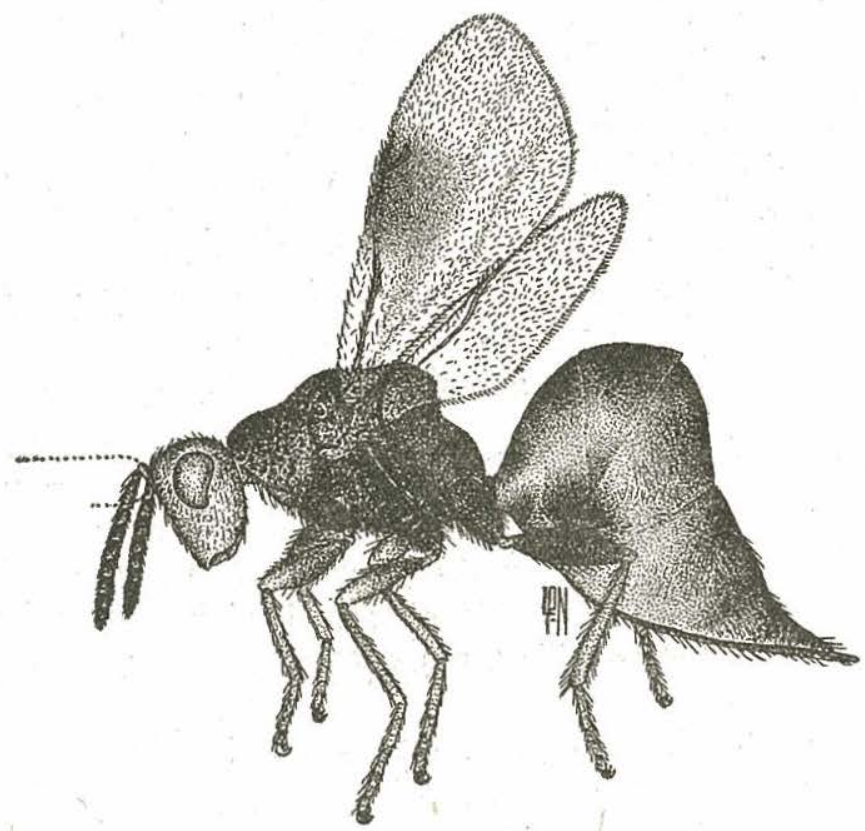

Figure 4.-Adult female wasp, Bephrata cubensis Ashmed, that attacks the seed of annonaceous fruits, greatly enlarged (original)

black. Legs testaceous except for slight infuscation on the femora. Umbilicately punctate, the head, thorax and petiole dull. Petiole short. Abdomen shiny, much compressed, slightly longer than the head and thorax combined, roundingly and prominently elevated from the base, then depressed downwards in a rounding curve to a pointed tip from which the ovipositor projects slightly. Frons with a deep antennal groove. Wings hyaline with a distinct fuscous cloud or infumation beneath the marginal vein.

Male unknown.

* This seed chalcid was reported by O. G. Anderson (determined by C. F. W. Muesebeck) as infesting one out of four fruits of "corazón", Annona reticulata, examined at ViMalba on October 27, 1931-Editor's Note. 
TWO IMPORTANT WEST INDIAN SEED-INFESTING CHALCID WASPS 111

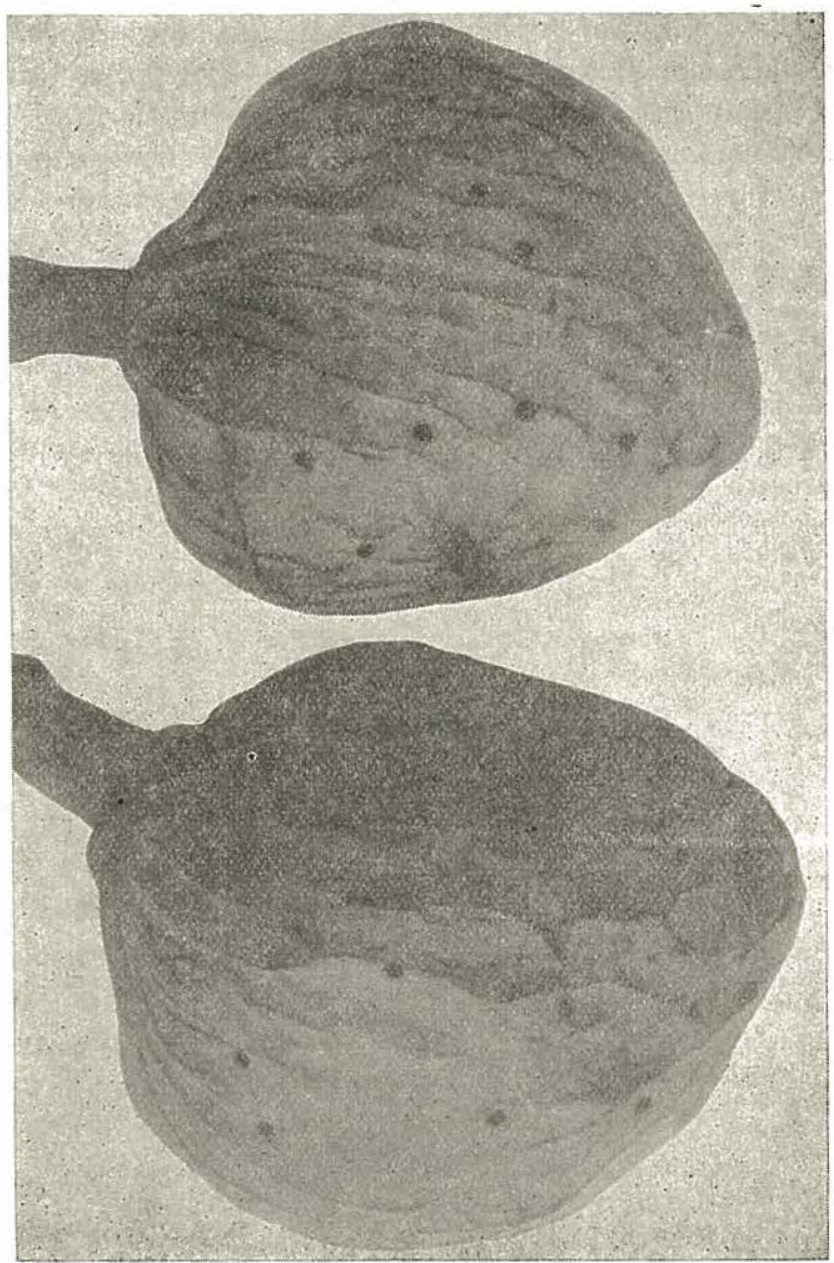

$\frac{\text { 월 }}{}$

옹

.ี

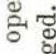

60 to

.

$\frac{7}{6} \stackrel{8}{8}$

$\rightarrow$ 赵

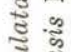

ปี

$\div$ (

ฐ

‡

ชิ รั)

4

! 


\section{OBSERVATIONS}

Fruits of "cachiman coeur-boeuf", Annona reticulata, were collected at Damien Haiti, on April 16, 1931 and were placed in rearing jars. On that date exit holes were already present in various fruits and during the period from the 17 th to the $24 \mathrm{th}$, a total of $17 \mathrm{fe}$ males were reared from this fruit. The adult Eurytomid wasp lays her eggs in the young developing fruits and the larvae develope inside of the seeds, gradually consuming them. The insect leaves the fruits as an adult, gnawing exit holes as shown in Fig. 5. Similar holes are very common in fruit of the "corosol", Annona muricata, in Haiti, and three adults were reared from this fruit May 3, 1931.

\section{REFERENCES}

1922 Gahan, A. B. A List of Phytophagous Chalcidoidea witb Deseriptions of Two New Species. Proc. Fnt. Soc. Wash., vol. 24, February.

1890 Howard, L. 0. A New and Remarkable Encyrtid: Is it Parasitic?, Insect. Life, vol 3, p. 147. 